\title{
ARTURA SANDAUERA TOPOGRAFIA TOŻSAMOŚCI
}

\author{
Marcin WOŁK (Uniwersytet Mikołaja Kopernika w Toruniu)
}

Za życia Artur Sandauer był przede wszystkim krytykiem — przenikliwym, bezkompromisowym, ale też zadufanym w sobie i bezinteresownie nieraz złośliwym (pamięta się charakterystyczne tytuły jego krytycznoliterackich książek i cykli artykułów: Dla każdego coś przykrego, Bez taryfy ulgowej, Źle o..., Ogniem i mieczem). Był także oryginalnym badaczem literatury i kultury — $\mathrm{w}$ tym relacji polsko-żydowskich któremu zawdzięczamy m.in. terminy „,autotematyzm” i ,allosemityzm”. Był wreszcie człowiekiem wzbudzającym gwałtowne emocje polityczne, a przy tym trudnym do ideologicznego zaszufladkowania. Wyrósł - co często podkreślał - w socjalistycznym domu, w latach młodzieńczych komunizował; pozostając bezpartyjny, przez całe życie wyznawał jednak poglądy lewicowe. Ten socjalista z przekonania w okresie PRL wielokrotnie dawał dowody politycznej niepokorności: występował przeciwko wulgarnemu socrealizmowi już na początku panowania tej doktryny w Polsce, na przełomie lat 40. i 50., za co zapłacił kilkuletnim ograniczeniem prawa publikacji (właśnie w okresie 1950-1954 bierze początek, podjęta zrazu w celach zarobkowych, intensywna aktywność translatorska Sandauera - tłumaczenia z rosyjskiego, francuskiego, greki, później także z niemieckiego i hebrajskiego) ${ }^{1}$. Jako jeden z pierwszych twórców krajowych publikował, i to pod własnym nazwiskiem, w „Kulturze” paryskiej ${ }^{2}$. W 1964 r. podpisał List 34, protestujący przeciw nasilającym się ograniczeniom wolności słowa - i nie wysłał potem podyktowanego przez władze sprostowania do „Timesa”, jak blisko jedna trze-

\footnotetext{
${ }^{1}$ Pojedyncze przekłady publikował od 1930 r. Podstawowe informacje biobibliograficzne o Sandauerze można znaleźć w: „Śnił mi się Artur Sandauer”. Rozmowy $i$ wspomnienia, zebrał i oprac. J. Baran, Kraków 1992 (Kalendarium życia i twórczości, oprac. J. Wróbel); Z. Macużanka, Sandauer Artur, PSB, t. 34, Wrocław-Warszawa-Kraków 1992-1993; oraz - omówienie najpełniejsze, choć również nie kompletne: Wspótcześni polscy pisarze $i$ badacze literatury. Stownik biobibliograficzny, oprac. zespół pod red. J. Czachowskiej i A. Szałagan, t. 7, Warszawa 2001 i uzupełnienia w t. 10, Warszawa 2007. Wiele cennych danych zawiera niepublikowana praca Ireny Karkuszewskiej „Problem tożsamości w prozie literackiej, paraliterackiej i dokumentarnej Artura Sandauera" (Uniwersytet Mikołaja Kopernika w Toruniu, 2005).

${ }^{2}$ Zob.: A. S. Kowalczyk, Sandauer i „Kultura”, [w:] Artur Sandauer. Pisarz, krytyk, historyk literatury, red. K. Hryniewicz, A. S. Kowalczyk, Warszawa 2014.
} 
cia pozostałych sygnatariuszy. Od 1981 r. był członkiem NSZZ „Solidarność”. W okresie stanu wojennego zignorował jednak powszechny wśród intelektualistów bojkot państwowych mediów, a nawet wszedł do fasadowej Narodowej Rady Kultury przy gen. Wojciechu Jaruzelskim. Zarazem to artykuł Sandauera o George'u Orwellu (Prawo do prawdy, Polityka $1987 \mathrm{nr}$ 8) utorował drogę do oficjalnej krajowej publikacji Roku $1984 \ldots$

Od pewnego czasu Sandauera krytyka, literaturoznawcę i enfant terrible polskiego życia intelektualnego w odbiorze społecznym - a przynajmniej akademickim - zaczął przesłaniać Sandauer prozaik, autobiograf, artysta. Za moment inicjalny tej fazy recepcji można uznać opublikowanie w 1991 r. przez Jerzego Madejskiego szkicu Mit Galicji w twórczości Artura Sandauera (Szczecińskie Prace Polonistyczne $1991 \mathrm{nr}$ 4), które zbiegło się z pośmiertnym wydaniem ostatniego tomu wspomnień krytyka-pisarza, zatytułowanych Bytem... W tym samym roku rozdział poświęcony Sandauerowemu zbiorowi opowiadań Śmierć liberała znalazł się w książce Józefa Wróbla Tematy żydowskie w prozie polskiej 1939-1987 (Kraków 1991). Już wcześniej Dorota Tubielewicz Mattsson opublikowała obszerny artykuł Artur Sandauer — filozofia mitu, interpretujący łącznie twórczość krytycznoliteracką i artystyczną Sandauera (Slovo 1990 t. 39) ${ }^{3}$. Kilka lat później ukazał się kolejny tekst Madejskiego: Problemy polskiego Żyda na przykładzie twórczości literackiej i krytycznej Artura Sandauera (w: Literackie portrety Żydów, red. E. Łoch, Lublin 1996) oraz artykuł Iwony Mityk „Śmierć liberata" - elementy groteskowe w opowiadaniach Sandauera (Kieleckie Studia Filologiczne 1996 t. 6; przedruk w: tejże, Inne spojrzenie. Groteska w prozie polskiej o wojnie i okupacji, Kielce 1997), a w kolejnych dekadach szkic Stanisława Gawlińskiego Sambor Sandauera (Teksty Drugie $2004 \mathrm{nr}$ 6; przedruk w: tegoż, Metafory losu. O wspótczesnej literaturze polskiej, Kraków 2005), seria artykułów piszącego te słowa: Pułapki świadomości. O labiryntowym cyklu opowiadań Sandauera (w: Cykl literacki $w$ Polsce, red. K. Jakowska, B. Olech, K. Sokołowska, Białystok 2001), Schodki, kanaty, strych. Przestrzeń i ruch w „Zapiskach z martwego miasta” (w: tegoż, Glosy labiryntu. Od „Śmierci w Wenecji” do „Monizy Clavier”, Torun 2009), On-ja Artura Sandauera (Litteraria Copernicana $2010 \mathrm{nr}$ 1) oraz tekst Hanny Gosk Sambor i okolica. Dwie opowieści geo(poli/poe)tyczne o tym, że w Galicji żylo się razem, ale osobno (przypadek A. Kuśniewicza i A. Sandauera) (Teksty Drugie $2014 \mathrm{nr} 6$ ). W stulecie urodzin opracowano tom zbiorowy Artur Sandauer. Pisarz, krytyk, historyk literatury (Warszawa 2014); nie tylko kolejność ról zawodowych wskazanych w podtytule tej książki, ale i tematyka artykułów, poświęconych w dużej części twórczości artystycznej bohatera, poświadczają, że proza Sandauera przechodzi zwycięsko próbę czasu, a Sandauer pisarz zdobywa przewagę nad krytykiem ${ }^{4}$.

W tym przeglądzie stanu badań nad dorobkiem prozatorskim autora Śmierci libera$\downarrow a$ trzeba również wspomnieć o z konieczności skrótowych, ale ważnych dla popularyzacji tej twórczości omówieniach w światowych encyklopediach i antologiach literatury żydowskiej czy holokaustowej oraz o przekładach jego opowiadań ${ }^{5}$. Warto też zwró-

\footnotetext{
${ }^{3}$ Zob.: http://www2.moderna.uu.se/slovo/Archives/1990-39/3.pdf (dostęp: grudzień 2015). Proza autobiograficzna Sandauera omówiona została na s. 70-75 tej pracy.

${ }^{4}$ Co nie znaczy, że o krytyku zupełnie zapomniano - zob. monografię G. Wołowca Nowocześni w PRL. Przyboś i Sandauer, Wrocław 1999.

${ }^{5}$ Zob. zwłaszcza: M. G. Levine, Artur Sandauer, [w:] Holocaust Literature, red. S. L. Kremer, t. 2, London-New York 2003. Z kolei w antologii Contemporary Jewish Writing in Poland (red. A. Polonsky, M. Adamczyk-Garbowska, Lincoln 2001), oprócz szkicu krytycznego o autorze, opublikowano pierwsze thumaczenie prozy Sandauera na język angielski - tytułowe opo-
} 
cić uwagę, że Sandauera-prozaika wśród innych wybitnych pisarzy polsko-żydowskich uwzględniają zarówno Jan Błoński w syntetycznym szkicu Autoportret żydowski w literaturze polskiej (w: tegoż, Biedni Polacy patrza na getto, Kraków 1994), jak i Eugenia Prokop-Janiec w artykule Żyd - Polak - artysta: o budowaniu tożsamości po Zagładzie (Teksty Drugie $2001 \mathrm{nr}$ 1). Wielokierunkowa i coraz intensywniejsza recepcja zdaje się potwierdzać obserwację Stefana Kisielewskiego z 1973 r. na temat wartości tego pisarstwa:

Sandauer dał mi swój wybór prozy wydany przez Wydawnictwo Literackie. Przypomniałem sobie te rzeczy, są znakomite. Śmierć liberała i Zapiski z martwego miasta zawierają fragmenty wstrząsającej literatury: krytyk to on bywa maniakalny i małostkowy, tu jest wielkość i groza. Umie niewielu słowami zarysować skomplikowaną sytuację, a na Wschodzie (w Samborze) było zawile: Ukraińcy, Polacy, Niemcy, Żydzi i - zagłada narodu żydowskiego. $Z$ niesamowitą precyzją opisuje tę zbrodnię, którą właściwie zapomnieliśmy, bo żyć z myślą o niej niepodobna. [...] Groza i bzdura matematycznie zorganizowane - maluje to Sandauer lepiej od Rudnickiego, rozgadanego bez precyzji. Wybitny pisarz, a na gwałt chce być krytykiem ${ }^{6}$.

Sandauer-prozaik miał dwóch mistrzów: Witolda Gombrowicza, od którego przejął groteskową poetykę i widzenie ludzkiej jednostki w nieprzezwyciężalnym uwikłaniu jej funkcji społecznych, i Brunona Schulza, z którym łączy go nie podobieństwo metod pisarskich, lecz głębokie przeżywanie przestrzeni i twórcze sięganie do żydowskiego rodowodu. W latach międzywojennych z oboma pisarzami się znał, o obu pisał jako krytyk, z Schulzem łączyła go niemal przyjaźń.

Własny dorobek literacki Sandauera, wobec obfitości jego pisarstwa krytycznego ${ }^{7}$, jest ilościowo skromny. Stanowią go cztery nieduże tomy prozy artystycznej i autobiograficznej: wciąż za mało doceniana Śmierć liberała z 1947 r. — w której przenikliwość obserwacji, dorównująca opowiadaniom obozowym Tadeusza Borowskiego, łączy się z techniką literackiej groteski ${ }^{8}$; W 2000 lat później (1956) — dziennik-reportaż dokumentujący obraz państwa Izrael w niespełna dekadę po jego utworzeniu, który pozostaje wciąż frapującą lekturą; Zapiski z martwego miasta (1963) — nowatorski formalnie zbiór ,autobiografii i parabiografii”, oraz wspomniana już autobiografia Bytem... (1991), doprowadzona chronologicznie do roku 1968.

We wszystkich tych utworach Sandauer ukazuje się jako par excellence pisarz przestrzeni. Widać to szczególnie wyraźnie w dokonywanych przez autora interpretacjach własnego rodowodu. Takie autointerpretacje przeprowadza on wielokrotnie, za każdym razem nadając pochodzeniu wymiar uogólniony i przedstawiając je jako rodowód kulturowy, a nie tylko genealogię rodzinną czy etniczną. Niemal zawsze też ujmuje ów rodowód w kategoriach geograficznych czy topograficznych. Co więcej — prawie każda autocharakterystyka Sandauera zaczyna się właśnie od danych przestrzen-

wiadanie ze Śmierci liberała (Death of a Liberal, przeł. M. Adamczyk-Garbowska). Całość tego zbioru była thumaczona na francuski i niemiecki - zob.: A. Sandauer, La Mort du liberal, Paris 1958; tenże, Der Tod eines Liberalen: Erzählungen. thum. i posłowie U. Usakowska-Wolff, M. Wolff, Bielefeld 2001.

${ }^{6}$ S. Kisielewski, Dzienniki, wyd. 2, Warszawa 1997, s. 760.

${ }^{7}$ Czterotomowe wydanie Pism zebranych Sandauera (Warszawa 1985), obejmujących teksty krytycznoliterackie, liczy w sumie ponad 2000 stronic.

${ }^{8}$ Więcej na ten temat zob.: M. Wołk, The Holocaust and the Grotesque: the Case of Artur Sandauer's Fiction, Jednak Książki / Books Now 2016 nr 6, s. 187-196. 
nych, jakby dla podkreślenia ich kluczowej roli w kształtowaniu tożsamości. Przytoczmy fragment otwierający Bytem ...:

Urodziłem się na wielokrotnym pograniczu: krajów, epok, kultur, dzielnic — w położonej o siedemdziesiąt kilometrów na południe od Lwowa austro-węgierskiej podówczas mieścinie, Samborze, która od drugiej wojny światowej weszła w skład ZSRR. Pograniczny był i rok mego przyjścia na świat - ostatni przed wybuchem pierwszej wojny, która miała doprowadzić cesarsko-królewską monarchię do rozpadu.

Za czasów mojej młodości Sambor należał do Polski; dominowała w nim kultura polska. Inteligencja żydowska mówiła — bardzo co prawda poprawną, za to mniej niż w Polsce centralnej rdzenną polszczyzną: brak było polskiego zaplecza. Za przykład może posłużyć język Brunona Schulza, który do polszczyzny ogólnej ma się tak jak język Kafki do ogólnej niemczyzny. Jeśli Kafka niemczyzną praską, to Schulz pisze polszczyzną galicyjską. Tak właśnie mówiliśmy i my (B 7) ${ }^{9}$.

Sandauer akcentuje przestrzenną, historyczną, kulturowo-językową pograniczność miejsca swoich narodzin - miejsca rozumianego także jako punkt na osi czasu i jego oddalenie od centrum. Zarazem jednak, przywołując nazwiska Kafki i Schulza, daje do zrozumienia, że w takich peryferyjnych przestrzeniach rodziły się idee i dzieła fundamentalne dla współczesnej kultury europejskiej, i sygnalizuje swoje pochodzenie ze szczególnego zagłębia dwudziestowiecznej literatury polsko-żydowskiej, jakim była wschodnia Galicja ${ }^{10}$. Geograficzną, sytuacyjną i towarzyską bliskość z Schulzem zaznaczał Sandauer wielokrotnie. Zawartą $w$ tych wzmiankach sugestię pochodzenia $\mathrm{z}$ dobrego miejsca na mapie można wzmocnić, przypominając, że w tym samym czasie co Sandauer i niemal po sąsiedzku urodził się i wychował inny wybitny pisarz polski, wywodzący się z diaspory żydowskiej — Julian Stryjkowski, którego przybrane nazwisko podkreślało więź z rodzinnym Stryjem, miasteczkiem niewiele większym od Sambora i położonym równie blisko Drohobycza ${ }^{11}$.

Jak zauważa Jagoda Wierzejska, galicyjskość - utożsamiana z wielokulturowością — jest dla Sandauera kategorią ważną, ale interpretuje on ją inaczej niż większość autorów z kręgu „mitu habsburskiego”, bez idealizowania wspólnoty ludów zjednoczonej pod panowaniem Franciszka Józefa ${ }^{12}$. Galicja to w ujęciu Sandauera nie tygiel, w którym rozpływają się granice, a odmienności przenikają, lecz obszar ostrych kon-

${ }^{9}$ Cytaty z utworów A. Sandauera oznaczam za pomocą skrótów: B - Bytem..., Warszawa 1991; W - W 2000 lat później. Pamiętnik izraelski, Warszawa 1956; Z — Zapiski z martwego miasta, [w:] Proza, wyd. 2, Kraków 1974. Cyfry po skrócie oznaczają numery stron.

${ }^{10}$ Wątek ten rozwija S. Gawliński, Sambor Sandauera.

${ }^{11}$ Zarówno Sambor, jak Stryj dzieli od Drohobycza dystans ok. $30 \mathrm{~km}$. Sandauer nie byłby wdzięczny za to przypomnienie, bo twórczości Stryjkowskiego, którego nazwał „piewcą brzydko mówiących", nie poważał; zob.: A. Sandauer, O sytuacji pisarza polskiego pochodzenia żydowskiego w XX wieku. (Rzecz, która nie ja powinienem byt napisać...), Warszawa 1982, s. 90-94. Charakterystyczne, że fragment dotyczący Stryjkowskiego bezpośrednio poprzedza w tej książeczce rozdział końcowy, który poświęcił Sandauer własnej twórczości. Widać w tej kompozycji dążenie raczej do wydobycia kontrastu (podobnie jest z omówionym wcześniej Adolfem Rudnickim, ,piewcą pięknie ginących”; tamże, s. 86-90) niż do zarysowania jakiejkolwiek wspólnoty. Usytuowanie na autorskiej mapie Galicji Sambora w miejscu Stryja, czyli „o siedemdziesiąt kilometrów na południe od Lwowa" (w rzeczywistości Sambor leży znacznie bardziej na zachód), wyglądać może na (nieświadomą?) próbę usunięcia rywala do schulzowskiego dziedzictwa, jakim mógł stać się Stryjkowski.

12 J. Wierzejska, Wątki galicyjskie w twórczości Artura Sandauera (,,Śmierć liberała”, ,Zapiski z martwego miasta”, „Bytem...”), [w:] Artur Sandauer. 
trastów kulturowych, etnicznych i społeczno-ekonomicznych. Również pisząc o „pograniczu", autor akcentuje nie tyle obszar wspólny, ile właśnie g r a n i c e. Dzieje się tak może dlatego, że określające jego autoidentyfikację „mity terenowe” (Z 143) związane są w mniejszym stopniu $\mathrm{z}$ regionem niż z samym rodzinnym miasteczkiem (,tym strasznym Samborem", jak się wymyka Sandauerowi, B 25). Widać to wyraźnie w naszkicowanej w Byłem... koncepcji ,psychologii lokalnej”:

jak w języku naukowym powiedzieć, że jesteśmy kameleonami, które nasiąkają barwami miejsc i godzin, że jak meduza od wody jesteśmy nie oddzieleni od pory dnia, od okolicy. Bez uwzględnienia owej psychologii lokalnej niepodobna jednak mówić o sztuce. [...] jak w języku abstrakcji wyrazić pojęcia tak ulotne, jak ,samborskość”, „drohobyckość”, ,galicyjskość”? Miasteczko galicyjskie jest już w swej topografii, nie mówiąc o atmosferze — inne niż kongresowe: bardziej koncentryczne, z Rynkiem i Ratuszem pośrodku. Taki był mój Sambor, taki Drohobycz Schulza (B 17-18).

Właśnie z rozkładu dzielnic rodzinnego miasta Sandauer wywodzi nie tylko cechy twórczości, ale też strukturę psychiczną — zarówno autora Sklepów cynamonowych, jak własną. Nie zadowala się przy tym ogólnym schematem układu przestrzennego „galicyjskiego miasteczka", rysuje mapę o wiele dokładniejszą. Oto jeden z takich opisów:

Miejsce mego urodzenia, Targowica, sąsiadowała z jednej strony przez Młynówkę z głębokim gettem, z drugiej — przez schodki — z Rynkiem, dzielnicą urzędów, szkół i kościołów. Fakt, że Rynek znajdował się na wzgórzu, miał dla mnie [...] znaczenie zasadnicze. Zstępując po schodkach do przeciętej na dwoje Młynówką dzielnicy żydowskiej zstępowało się zarazem na dno drabiny socjalnej. Nie od razu jednak! Na lewym brzegu, czyli na Targowicy, domy były jeszcze nie tak odrapane, a język polski rozbrzmiewał na równi z żydowskim. W dni jarmarczne, kiedy plac mrowił się od chłopskich furmanek, dochodził tu trzeci - ukraiński. [...]

Przez mostek na Młynówce wchodziło się z Targowicy w samo sedno Czarnego Lądu, w prawobrzeżne getto. Na Blichu, gdzie - wokół synagogi, cmentarza i trupiarni - przykucnęło kilkadziesiąt ruder z oknami na wpół zasłoniętymi przez zgniłe gonty, mówiło się wyłącznie - czy raczej „szwargotało” - po żydowsku; w piątkowe wieczory zza oświetlonych szyb dolatywały także pieśni hebrajskie. W skwarne popołudnia woń rynsztoków biła pod niebiosa. Dopiero w miarę posuwania się w głąb Blichu $\mathrm{z}$ odorem tym mieszał się zielony zapach wody, a w odgłosy zabaw dziecięcych wkradał się inny głos, odległy. To rzeka Dniestr, którą dostrzegało się stając na skraju zabudowań, torowała sobie pracowicie drogę przez szuwary ${ }^{13}$ (P 144-145).

Mamy więc cztery dzielnice: Rynek, Naddniestrze, Blich i wciśniętą pomiędzy nie Targowicę. Granice naturalne między nimi (stok wzgórza i rzeka) nakładają się na podziały etniczne, wzmacniając różnice kulturowo-religijne, społeczne i ekonomiczne. Nie są to jednak granice nieprzekraczalne: na wzgórze prowadzą schodki, przez rzeczkę przerzucono mostek. Również wyłaniająca się z przytoczonego fragmentu lista czterech języków (polski, ukraiński, jidysz, hebrajski) jest tylko uproszczonym odwzorowaniem bardziej złożonej rzeczywistości lingwistycznej. Polszczyzna Sambora była, jak już wiemy, regionalna, ,galicyjska” (a więc z naleciałościami wschodniosłowiańskimi i niemieckimi), choć czasem w okolicach Rynku — z ust przybyłych z zachodu Polski urzędników, nauczycieli, księży, wojskowych — rozbrzmiewały pewnie także

${ }^{13}$ Walory tego opisu docenił M. Pollack, umieszczając go w swojej książce-wypisach Po Galicji. O chasydach, Hucułach, Polakach i Rusinach. Imaginacyjna podróż po Galicji Wschodniej i Bukowinie, czyli Wyprawa w świat, którego nie ma, przeł. A. Kopacki, Olsztyn 2000. 
inne dialekty. Niejednorodność musiała być jeszcze wyraźniejsza w wypadku języka hebrajskiego - w bóżnicy, gdzie modlili się dziadkowie Sandauera ze strony ojca, i podczas liturgii sobotniej $\mathrm{w}$ ich domu słyszało się zapewne odmianę misznaicką w wymowie aszkenazyjskiej (a także podobnie wymawiany język aramejski); u dziadków ze strony matki natomiast „klasyczną”, biblijną (zrekonstruowaną) hebrajszczyznę wujów syjonistów, i to używaną na co dzień, a nie tylko jako język święty ${ }^{14}$. W domu stykał się także młody Sandauer z językiem niemieckim (w odmianie austriackiej), w szkole poznawał grekę, łacinę, francuski. „[...] wszystkiego po trochu. Moja wielojęzyczność ma tutaj swoje korzenie” (B 24) - stwierdza pisarz. „Tutaj” — to znaczy w pośredniej, pogranicznej dzielnicy, w której przyszedł na świat. Gdyby urodził się na Blichu, pewnie nie trafiłby do I Gimnazjum Klasycznego im. Adama Mickiewicza. Gdyby jego ojciec posiadał kamienicę w Rynku, nie wiedziałby z kolei, jak pachnie „Czarny Ląd”. I w jednym, i w drugim wypadku nie stałby się tym, kim był - człowiekiem pogranicza.

Można by więc powiedzieć, że Targowica - łącząca wpływy żydowskie, polskie i ukraińskie - jest w prywatnym porządku znaczeń Sandauera miniaturą zmitologizowanej Galicji z literatury „małych ojczyzn”. Można by, gdyby nie to, że istota Sandauerowej Targowicy polega na jej relacyjnym usytuowaniu wobec dzielnic pozostałych; nie jest ona żadnym mikrokosmosem, nie jest w ogóle całością autonomiczną, lecz elementem większego układu przestrzenno-społecznego. Oglądany w wymiarze horyzontalnym układ ów obejmuje centrum (Rynek), peryferie (Blich) i półperyferie (Targowicę) oraz pozaperyferyjny, stanowiący subekumenę teren Naddniestrza, pod pewnymi względami różny od wszystkich pozostałych (bo podlegający w większym stopniu porządkowi natury niż cywilizacji), pod innymi zaś wykazujący łączność z Rynkiem. Obszary centralny i skrajny — Rynek i Naddniestrze — są u Sandauera wartościowane pozytywnie, wartość pozostałych maleje wraz z rosnącym oddaleniem od centrum.

Na ten ,poziomy” obraz nakłada się wertykalne zróżnicowanie wzdłuż osi aksjologicznej góra - dół, z wysoko położonym, trudno dostępnym Rynkiem (zamożnym, polskim, europejskim) jako naturalnym celem aspiracji oraz Blichem jako przestrzenią, od której się ucieka i w którą łatwo się ,stoczyć”, ale też którą trzeba przebyć, by dostać się na niemal równie co Rynek pożądane Naddniestrze:

\begin{abstract}
paradoks terenowy mojej młodości polegał na tym, że nad Dniestr szło się przez Blich, że droga do raju prowadziła przez piekło. Aby uciec w letnie dni od skwaru i fetoru Targowicy, trzeba było mianowicie zanurzyć się w skwar i fetor jeszcze większy, trzeba było przez gęsto pokryty rynsztokami teren getta przedostać się na pola nadrzeczne. Szedłem tamtędy jakby zagrożony jakimś wewnętrznym niebezpieczeństwem. Zdawało mi się, że niechbym stąpnął nieco mocniej, a runę przez tę powierzchnię nieszczelną w jakiś podziemny labirynt, którego obsesyjną mapę nosiłem w sobie (P 148-149).
\end{abstract}

Okazuje się więc, że jest coś jeszcze niższego niż Blich — ów labirynt „rynsztoków, przejść i przełazów” (P 149). Jego kwintesencję stanowi kanał ściekowy, „który w centrum getta otwierał półtorametrową, cieknącą żółtym wysiękiem, paszczę. Był to główny odbyt całego miasta, które tam, na górze, maskowało dyskretnie swą podziemną łączność z Blichem przy pomocy płyt kanałowych, ale tu załatwiało się otwarcie

\footnotetext{
${ }^{14}$ Tej właśnie uczył się Artur Sandauer jako dziecko: „Wujowie nastręczyli mianowicie rodzicom młodego «chaluca», który wyuczył mnie hebrajszczyzny - nie tradycyjnej, modlitewnej, lecz nowoczesnej, wymawianej ze śródziemnomorska, tej, jaką się mówi dziś w Izraelu; nie aszkenazyjskiej, lecz sefardyjskiej” (B 11).
} 
i bez żenady” (P 149). „Zachodni” Rynek i „wschodnie” Naddniestrze wyznaczają dwa kierunki oddalania się od tego podziemia. Charakterystyczne, że oba obszary — pomimo wszelkich różnic - opisywane są przez Sandauera w porządku europejskiej kultury wysokiej: „Jeżeli Rynek układał mi się w całość śródziemnomorsko-klasyczną, to Naddniestrze kojarzyło mi się z jakąś leśmianowską słowiańszczyzną, z pokusą zmysłową i grzechem” (P 145). Nawet „dzikie” nadrzeczne łozowiska wyglądają „niby płótno Breughla" (P 145) i łączą się z literaturą (nb. w wydaniu twórcy, który dzięki mistrzostwu poetyckiemu z „Lesmana” stał się „Leśmianem”).

Zrekonstruowany tu symboliczny układ przestrzenny, przypominający zaświaty Dantego - z lejem Piekła, górą czyśćcową i dostępnym tylko dla wybranych Rajem - jest scenerią dynamicznego procesu: rozłożonej na pokolenia wspinaczki rodu Sandauerów z Blichu na Rynek, wędrówki od ortodoksyjnej żydowskości ku nowoczesnej europejskości, szlakiem wyznaczonym przez identyfikację z kulturą polską („Rynek reprezentował Zachód, Europę, kulturę, ku którym drogą była polskość”, B 13). Dzieje rodziny zostają bowiem ukazane przez Sandauera jako historia asymilacji, ta zaś jako ruch w przestrzeni:

dziadek Izrael [...] pół wieku temu przeniósł się z matecznika plemiennego, Blichu, na teren pośredni, jakim była Targowica. [...] Przenosząc się tutaj, nie przewidział jednak dalszych konsekwencji swojego czynu: oto że daje w ten sposób początek migracji naszej rodziny do dzielnicy polskiej (P 99).

To nakładanie się czynników temporalnych na spacjalne, historii na mapę, sprawia, że moment narodzin Artura Sandauera można przedstawić jako punkt w pół drogi do polskości, miejsce postoju, etap. Urodzenie „,W drodze” narzuca bohaterowi przymus kontynuowania rodzinnej wędrówki, w myśl zasady: „,co dla niego [tj. ojca] było punktem dojścia, dla mnie było już wyjściem” (P 103). Najpewniejszym zaś sposobem ostatecznego wspięcia się na Rynek wydaje się edukacja i jak najpełniejsza akulturacja:

Uczęszczałem do jego [tj. Rynku] szkół, na jego balustradach i amorkach uczyłem się poczucia piękna. Cóż dziwnego, że stał się on dla mnie symbolem kultury — zwłaszcza tej grecko-łacińskiej, jaką czerpałem z jego klasycznego gimnazjum, że pierwsze moje próby literackie utrzymane były w tym właśnie klasycyzującym stylu, a jako studium obrałem filologię starożytną, która miała mnie — przynajmniej duchowo - przeprowadzić do Rynku? (P 145).

We właściwy sobie deterministyczny sposób Sandauer wywodzi z opisanego początkowego układu przestrzennego swoją biografię: młodzieńczą miłość do „mieszkanki nadrzecza” („Kochamy się [...] nie tyle w osobach, co w światach, do których za ich pośrednictwem spodziewamy się zyskać dostęp [...]”, P 146), postparnasistowskie wiersze gimnazjalne (jeden pochwalił sam Julian Tuwim — będący ucieleśnieniem możliwości awansu ze świata żydowskiego na polski Parnas), studia klasyczne i debiut naukowy - rozprawę o sielankach Teokryta... Swe przedwojenne (a może także powojenne) życie widzi więc Sandauer jako kontynuację podjętej kilka generacji wcześniej wyprowadzki z Blichu i wspinaczki na wysoki Rynek:

Urodzony [...] na pograniczu dwu narodowości i klas, na dwuznacznej Targowicy, za sobą miałem siedlisko żydowskiej nędzy i ciemnoty - Blich; przed sobą, na wzgórzu — nasz małomiejski Rynek. Do tej dzielnicy kultury i polszczyzny musiałem — najdosłowniej - się wspinać. Przez zapach rynsztoków, przez charkot handełesów, przez zawodzenie żebraków dobiegałem do schodków, na których szczycie przystawałem na chwilę, aby otrząsnąć się ze wszystkiego, co przylgnęło po drodze, usztywnić się i ucywilizować (P 119). 
Jednak przestrzeń dzieciństwa nie daje się tak po prostu opuścić — wnika do wnętrza człowieka, jej struktura staje się jego strukturą. Autobiograficznemu bohaterowi Sandauera uświadamia to widok ścieku miejskiego uchodzącego na Blich:

\begin{abstract}
Nie mogłem — na widok tej strużki zaropiałego błota — opędzić się od myśli o jej proweniencji: w ten więc sposób dawały tym na dole znać o swym istnieniu wille i urzędy, szkoły i gimnazja? Tym więc podszyty był rynkowy klasycyzm? A czyż mój własny klasycyzm - wszystkie te róże i zachody, te przekłady z parnasistów, cała ta kurczowa czystość mojej postawy — nie były podszyte czymś podobnym: lękiem przed stoczeniem się w podziemia Czarnego Lądu? Ten brud i nędzę nosiłem w sobie [...] (P 149).
\end{abstract}

Inaczej mówiąc: z Blichu można się wyprowadzić, ale całkowicie od Blichu uciec się nie da, zawsze bowiem zabiera się ze sobą jakąs jego cząstkę, niczym - używając Sandauerowskiej metafory - błoto, które przylgnęło do spodni. Mieczysław Rosenzweig - fikcyjne alter ego pisarza z noweli włączonej do Zapisków... - którego aspiracje do polskości prowadzą wprost ku nienawiści do żydostwa (i do samego siebie), wspinając się po tych samych samborskich schodkach na randkę z córką gimnazjalnego polonisty, „podkasuje mankiety spodni” (P 123), by broń Boże nie wnieść na Rynek nieczystości z Blichu, by nie zdradzić, że ma z nimi cokolwiek wspólnego. Podobną obsesję czystości dostrzega Sandauer w swoich młodzieńczych próbach literackich i w niej też widzi przyczynę ich artystycznej klęski: „wchodząc w świat kultury swoimi pierwszymi utworami - tarłem je tak długo, aż ścierałem z nich wszelki znak życia i autentyczności” (P 119).

Starcie śladów przejścia z dzielnicy do dzielnicy, ze świata do świata (widzimy, jak wszechobecna w tekstach Sandauera jest przestrzenna metaforyka), usunięcie owych „znaków życia”, pozbawia autentyczności nie tylko literaturę, lecz także ludzką tożsamość. Takie jest, w ujęciu Sandauera, ryzyko bezwarunkowej asymilacji, którą przecież symbolizuje wspinaczka na Rynek - płaci się za nią sztuczną, nieprawdziwą egzystencją człowieka bez korzeni i bez właściwości. Komentując ,parabiograficzne” Urywki z pamiętników Mieczysław Rosenzweiga, a zarazem własne próby poetyckie z międzywojnia, Sandauer formułuje polemiczną wobec Jean-Paula Sartre'a ${ }^{15}$ koncepcję autentycznej żydowskiej tożsamości w świecie nowoczesnym, tożsamości „Żyda już zasymilowanego i umieszczonego na pograniczu dwu narodowości”. Może być ona jedynie „wiernością wobec własnego rozdarcia, wobec własnej - nieautentyczności" (P 119). W odniesieniu do pracy pisarskiej to rozpoznanie przekłada się na „topograficzne” postanowienie twórcze: „na przyszłość w tym, co będę pisał, pozostanę wierny sobie i miejscu, skąd się wywodzę: nie Rynkowi ani Blichowi, lecz Targowicy" (P 121).

Artur Sandauer jako bohater swoich utworów, mimo „rynkowych” aspiracji, „nie podwija nogawek”, nosi na sobie ślady blichowego „błota”, a w sobie „mapę podziemnego labiryntu" - i to go ratuje w czasie Holokaustu, gdy wraz z całą żydowską ludnością Sambora zostaje przesiedlony na teren przyszłego getta. „Marzenie o przeprowadzce w końcu się jednak zrealizowało - tyle, że w kierunku wręcz odwrotnym", komentuje z gorzką ironią (B 13). Na Blich trafiają zarówno mieszkańcy Targowicy, jak i „panowie z Rynku” (B 12), staje się bowiem jasne, że ten ostatni był dzielnicą polską tylko ,jeśli chodzi o język, nie, jeśli o mieszkańców” (P 158) $)^{16}$. Za sprawą

${ }^{15}$ Por.: J.-P. Sartre, Rozważania o kwestii żydowskiej, przeł. J. Lisowski, Warszawa 1957.

16 Jest to zgodne z informacjami, jakie podaje W. Podoliński w pracy Sambor i okolica. Przegląd krajoznawczy (Sambor 1937): „Miasto dzisiejsze [...] liczy 23000 mieszkańców bez wojska, w tym Polaków 58,8\%, Rusinów 16,5\% i Żydów 28,7\%. Ci ostatni zamieszkują śródmieście [obejmowało Rynek - M.W.] i Blich, a reszta ludności przedmieścia i nowsze dzielni- 
Niemców dokonało się okrutne zjednoczenie Narodu, zredukowanie trzech — jak się po czasie okazuje - dzielnic żydowskich do jednej, Blichu.

Tam powstało getto, otoczone drutami, ale tylko $\mathrm{z}$ dwu stron. $\mathrm{Z}$ obu pozostałych miało granice naturalne: z jednej Młynówkę, z drugiej - „okopisko”: przez furtkę w cmentarnym murze można się było wydostać na pola naddniestrzańskie (B 13).

W świecie udosłownionych przez okupację znaczeń — z Rynkiem „bardziej niedostępnym i europejskim niż kiedykolwiek" (P 158) — Naddniestrze wciąż pozostaje obszarem upragnionej wolności. Natomiast „święto-przeklęty” (P 157), biały/czarny Blich „Czarny Ląd” jako przestrzeń Zagłady zostaje naznaczony jeszcze większą niż dotąd ambiwalencją. W groteskowym wyolbrzymieniu szabasowego eruw chacrot getto, które „owinęło się kłębkiem drutów” (P 158), przypomina bowiem jedną wielką przestrzeń domową ${ }^{17}$, jest to jednak — zgodnie z aluzją do utworu Dostojewskiego zawartą $\mathrm{w}$ tytule Zapisków z martwego miasta - $\mathrm{do} \mathrm{m}$ u marł y c h .

Istotna modyfikacja wartościowań dotyczy także Rynku z jednej strony, a odrażających „podziemi” z drugiej. Ten pierwszy staje sie mianowicie przestrzenią śmierci, blichowe labirynty natomiast - miejscem ocalenia ${ }^{18}$. Sandauer nie relacjonuje obszerniej wydarzeń Szoa. Ich literacko przetworzony obraz daje w Śmierci liberała. W autobiograficznym Bytem... dla przedstawienia doświadczeń lat 1942-1943 wprowadza zastępczą relację swojej siostry, Ireny Sandauer-Glanz, i matki, Berty Sandauer. W Zapiskach ... ogranicza się do kilku wyrazistych epizodów — także wykorzystujących symbolikę topograficzną. Najbardziej rozbudowany z nich przedstawia zbiorową ucieczkę podczas jednej z akcji likwidacyjnych znanym nam już kanałem ściekowym. Bohater Sandauera zrazu przemieszcza się z grupą, doświadczając zjednoczenia $\mathrm{z}$,wielką czarną wspólnotą" ginącego narodu (P 165). Potem jednak powstrzymuje odruch wspólnej wspinaczki ku klapie studzienki, otwierającej się na płycie Rynku, gdzie czekają już „uzbrojone postaci”, i podczas gdy ludzki „strumień rwie wciąż naprzód, wyrzucając jednego za drugim na powierzchnię Rynku” (P 164), on kryje się

ce" (s. 37). Wg tego samego źródła (s. 38-39) IV dzielnica - Blich — obejmowała m.in. ulice Blich i Targowica. Wg innych źródeł (Nowa encyklopedia powszechna PWN, t. 5, Warszawa 1997, s. 713) w 1939 r. Żydzi stanowili 42\% mieszkańców Sambora (ok. 6 tys. z ok. 14 tys. mieszkańców ogółem). Różnica $\mathrm{w}$ danych wynika prawdopodobnie $\mathrm{z}$ uwzględnienia w źródle międzywojennym także przedmieść (być może celowe, by podkreślić „polskość” miasta). Na wypieranie z Rynku firm żydowskich wskazują wydrukowane w książeczce Podolińskiego reklamy sklepów z Rynku: „Nowootwarty chrześcijański sklep bławatny pod firmą H. Gaszyński, Sambor, Rynek 26, Linia A-B [...]”; „Nowo otwarty chrześcijański Sklep galanteryjny [...], Rynek 31”. Kupcy żydowscy musieli wskazać inne atuty niż wyznanie: „Rok założenia 1878. Znany z solidności i niskich cen skład porcelany [...] J. Liberman, Rynek 23”; W. Podoliński, Sambor i okolica, s. 80-81, pisownia oryginalna.

17 „Eruw chacrot («zmieszanie podwórek») polega na tym, że w szabat mieszkańcy jednej okolicy, począwszy od kilku domów aż do całej ulicy czy nawet miasteczka, łączą się w jeden prywatny teren. Umożliwia to ludziom przenoszenie rzeczy przez cały obszar eruw, mimo że normalnie w szabat niczego nie wolno nosić poza granicami swego domu. Żeby eruw zadziałał, daną okolicę musi otaczać prawdziwy lub symboliczny mur [...]"; A. Unterman, Encyklopedia tradycji i legend żydowskich, przeł. O. Zienkiewicz, wyd. 2 popr., Warszawa 2000, s. 88. Sandauer pisze o Samborze przedwojennym: „W święta gotowano i jadano wspólnie. Domy połączone były — na zasadzie «ejruwu» — drutami, by nie ruszając rytuału wolno było przenosić jedzenie przez ulicę” (B 8). Po zamknięciu getta ,druty, dawniej tylko zaznaczone, teraz zgęstniały i odgrodziły dzielnicę [...]" (P 157).

${ }^{18}$ Więcej na ten temat w: M. Wołk, Schodki, kanaly, strych, s. 83 n. 
samotnie w jednej z bocznych odnóg owego labiryntu, którego mapę od zawsze nosił w sobie. To go uratuje.

Podziemne zjednoczenie $\mathrm{z}$ narodem jest więc chwilowe i przede wszystkim mentalne, a dokonuje się tuż przed ostateczną zagładą żydowskiej społeczności Sambora. Bezrozumna - czy po prostu: rozpaczliwa - ewakuacja uciekinierów z getta do dzielnicy, która od dziesięcioleci była przedmiotem ich marzeń, to wypowiedziana w języku samborskiej topografii metafora pułapki asymilacji. Niewyjście Sandauera na Rynek jest oczywiście znaczące. W porządku dosłownym warunkuje ono ocalenie; potraktowane jako metafora — oznacza rezygnację z samobójczej (tożsamościowo) asymilacji, dokonującej się za cenę zapomnienia o własnym rodowodzie: o Blichu i zwłaszcza o Targowicy. Rezygnując z nierealistycznych nadziei na ocalenie, Sandauer, mówiąc w przenośni, pozostaje w dzielnicy swego urodzenia: pogranicznej, niejednorodnej, „targanej” sprzecznościami, przejściowej. W rzeczywistości — jeśli wierzyć autobiograficznej relacji — było zresztą podobnie:

Zdając sobie sprawę, że likwidacja getta jest kwestią dni, błąkałem się po aryjskiej stronie - zarośnięty, brudny, bez dokumentów. Po śmierci kolegów plan gromadnego wyjścia za druty stał się niewykonalny; pozostawało wyjście w pojedynkę. Że jednak g e t to kusiło jeszcze ciepłą strawą i przytułkiem, więc wybrałem drogę pośrednią. Zachodziłem tam za dnia, noce spędzając w n a d r z e c z u [...].

Gdy wieczór był deszczowy, szukałem noclegu w okolicach R y n k u (P 167, podkreśl. M.W.).

Wędrówki między dzielnicami - wszystkimi z wyjątkiem Targowicy, „pustej teraz, dostępnej jedynie psom i kotom" (P 158) — trwające aż do znalezienia schronienia u ukraińskiej rodziny, formują ostatecznie tożsamość pograniczną: rozszczepioną, chwiejną, niestabilną, „bezdomną”. W ujęciu Sandauera jest to, jak pisałem, jedyna autentyczna tożsamość Żyda po Zagładzie. Żyda niereligijnego i, trzeba teraz dodać, mieszkającego poza Izraelem. Bowiem w mojej rekonstrukcji topograficzno-tożsamościowej narracji Sandauera zabrakło jednego elementu — punktu odległego na mapie, ale dla poczucia tożsamości autora istotnego jako stały układ odniesienia. Aby należycie uchwycić jego rolę, musimy powrócić do dzieciństwa pisarza i do jego wujów syjonistów:

\begin{abstract}
Jeszcze za życia rodziców [matki] (a moich dziadków) dwaj najmłodsi synowie (a moi wujowie) emigrowali do Palestyny. Po ich śmierci pozostał najmłodszy, który też szykował się do wyjazdu. [...] Czterej starsi opuścili dom rodzicielski jeszcze za życia dziadków. Jeden osiadł we Wiedniu jako prokurent bankowy. Pisywał rzadko: znak życia przysłał jesienią 1942 roku. Była to wyrzucona widocznie z pociągu niemiecka kartka: „Jadę w nieznanym kierunku”. Następny po nim zginął jeszcze w 1916 roku na froncie włoskim jako żołnierz austriacki. Dwaj dalsi zginęli za okupacji.

[...] różnica między losami czterech wujów pozostałych w Europie a tych, którzy emigrowali, jest znamienna. Ocalał — kto wyjechał (B 10-11).
\end{abstract}

Wujów ocalałych dzięki emigracji do Erec Israel oraz matkę i siostrę, które wyjechały tam po wojnie, odwiedzał Sandauer kilkakrotnie. Syn pisarza, Adam Sandauer, powiedział, że „ojciec jeździł do Izraela głównie z powodu rodziny”"19. Jednak, niezależnie od motywów, z różnych tekstów autora, a zwłaszcza z ,pamiętnika izraelskiego”, przebija także sympatia, serdeczność, nawet rodzaj patriotyzmu wobec Państwa Żydowskiego. Jest to zresztą postawa widoczna u wielu polsko-żydowskich twórców tego pokolenia (np. u Stryjkowskiego czy Kazimierza Brandysa), kibicujących z oddali drugiej oj-

${ }^{19}$ Cyt. za: I. Karkuszewska, „Problem tożsamości w prozie literackiej”, s. 68. 
czyźnie. Sandauer, podczas pierwszej wojny izraelsko-arabskiej (1948) przebywający we Francji, zgłosił się nawet do izraelskiej komisji wojskowej (,jeśli przeżyję, wrócę do Polski" - informuje Jerzego Putramenta, zanim okaże się, że został odrzucony; B 114). Namawiany przez Curzia Malapartego do pozostania w Paryżu — na tym Rynku rynków, gdzie nie mógł już wprawdzie spotkać Paula Valery’ego, poznał za to (,ale jakież to mogło być «za to»?", B 110) nową śmietankę towarzysko-intelektualną Francji z Sartre'em na czele — rozważa:

Problem samookreślenia stanął znów przede mną w całej ostrości. Żyd czy Polak? A może - jedno i drugie? Wracać czy nie wracać? O tym, by wsiąknąć w polską emigrację, którą zawsze odczuwałem jako coś obcego, mowy być nie mogło. Wybór, jeśli istniał, to między Izraelem a Polską: innego nie znałem i znać nie chciałem (B 114) ${ }^{20}$.

W roku 1955 Sandauer po raz pierwszy odwiedza Izrael. Relacja z tej wizyty, zatytułowana $W 2000$ lat później, to do dziś interesujący, bynajmniej nie bezkrytyczny reportaż o odradzającym się po wiekach państwie, ale także dalszy ciąg autoanaliz pisarza. Uderza w nim, że pomimo widocznej sympatii do Izraela i Izraelczyków znacznie silniejsza jest identyfikacja Sandauera $\mathrm{z}$ diasporą. Sabry wychowane na pustyni nie tylko nie mają żadnego sentymentu dla „mieściny rosyjskiej czy galicyjskiej” (W 30), ale też wyglądają, zachowują się i myślą zupełnie inaczej niż ludzie, których pisarz znał do tej pory, i niż on sam, przeto trudno z nimi znaleźć głębsze porozumienie. Interesują go jako „nowi Żydzi”, jako przyszłość narodu, jednak prawdziwą więź odczuwa $\mathrm{z}$ odnajdywanymi po latach emigrantami z rodzinnych stron, z którymi rozmawia po polsku albo „po żydowsku” - co dla autora znaczy zawsze: $w$ jidysz, nie po hebrajsku. W Tel Awiwie bowiem Sandauer nieustannie - takie przynajmniej wrażenie odnosi czytelnik jego relacji — napotyka ludzi posługujących się najchętniej polszczyzną czy jidysz. Co więcej, raz po raz natyka się na swoich dawnych kolegów szkolnych. I z tymi właśnie Izraelczykami polskiego pochodzenia ${ }^{21}$, stanowiącymi gatunek ginący, lecz znaczący, odnajduje najpełniejsze porozumienie, nawet jeśli ich środkowoeuropejska tożsamość nie zawsze jest od razu widoczna:

Wybrałem się onegdaj z odczytem do jednego z kibuców. Jechałem tam nie bez termy, uprzedzony, że zetknę się z elitą inteligencji izraelskiej. Tremę tę spotęgowało jeszcze parę wymienionych nazwisk, których asyryjsko-babilońskie brzmienie przypominało mi krwawą atmosferę Salambo. Jakże przyjemnie byłem zaskoczony, kiedy pod tą egzotyczną szatą odnalazłem galicyjskich adwokatów, profesorów, lekarzy, starych znajomych, których uważałem od dawna za nieżyjących, a którym tuż przed wybuchem wojny udało się wyemigrować do Palestyny (W 56-57).

Uderzające porównania. Nazwiska hebrajskie, niejako zakrywające pierwotną tożsamość, przedstawione są tu jako coś obcego (kolosalna odległość historyczna „asyryjsko-babilońskiej" fonetyki) i nieledwie groteskowego (skojarzenie z krwawymi dziejami Kartaginy), paradoksalnie ni ż̇ dowskiego. Efekt obcości wzmacnia jeszcze hebrajska pisownia:

${ }^{20}$ Decyzja o powrocie do Polski nie była chyba jednak łatwa, skoro Sandauer pisze: „Wracałem w stanie ostatecznej depresji [...]" (B 115). Musimy mu również wierzyć na słowo, gdy stwierdza, że Malaparte myli się, relacjonując w swoim Journal d'un étranger à Paris ich rozmowy: „W istocie, stanowiska nasze były odwrotne, niż podaje: to on namawiał mnie do pozostania w Paryżu, to ja obstawałem przy powrocie"; tamże. Inaczej relacjonuje przebieg tych rozmów C. Malaparte; por.: Journal d'un étranger à Paris [1967], Paris 2014, s. 56-61.

21 „Mało kto u nas wie, że mamy w Izraelu coś w rodzaju kolonii kulturalnej, jakieś kilkadziesiąt — a może więcej — tysięcy ludzi, którzy umieją i chcą czytać po polsku” (W 52). 
Widząc [...] na wywieszce sklepowej napis „LMBRGR”, skłonni jesteśmy przypuszczać, że to jakiś Tybetańczyk Lama Baragar zawędrował do Tel-Awiwu. Na szczęście, transkrypcja łacińska po lewej stronie szyldu poucza nas, że to po prostu stary znajomy ze Lwowa - p. Lemberger (W 90).

Zupełnie jakby pisarz po raz pierwszy zetknął się z językiem hebrajskim.

Niechęć Sandauera do hebraizacji nazwisk jest bardzo znamienna i zostaje uzasadniona we właściwy temu autorowi, prowokacyjnie jaskrawy sposób:

Powiecie, że to drobiazg. Ale kryje się w tym przecie tendencja, aby wymazać 20 wieków, kryje się niechęć do żydostwa, jakim je urobiły tysiąclecia, kryje się — pod pozorem patriotyzmu - swoisty antysemityzm (W 55).

Ta filipika jest częścią sformułowanej poniewczasie odpowiedzi Sandauera na przypiętą mu w niektórych środowiskach Izraela łatkę ,,asymilatora”. Wydaje się, że pisarz odróżnia od asymilacji rozumianej jako zatarcie różnicy („tendencja, aby się ujednolicać, a więc - asymilować, istnieje właśnie u was [tj. Izraelczyków]”, W 55) asymilację polegającą na nasiąkaniu elementami kultury krajów osiedlenia, której istotą jest nie z a s tę powanie kultury żydowskiej, lecz wzbogacanie jej o unikatową mieszankę wpływów i niejako nanoszenie śla dó w p r z e j ś c i a przez rozmaite obszary geograficzno-kulturowe.

Taka asymilacja jest przeciwieństwem sztucznego zubażania tożsamości i upodobniania się do otoczenia. Przypomina raczej określany tą samą nazwą biologiczny proces przyswajania substancji pobranych z zewnątrz i ich przemiany na składniki własnego organizmu. Dlatego lekkomyślne czy koniunkturalne porzucanie nazwisk, będących pozostałością wędrówki narodu żydowskiego w czasie i przestrzeni - a tym jest dla autora zarówno sztuczne polonizowanie ${ }^{22}$, jak i hebraizowanie nazwisk — zakrawa w oczach Sandauera na barbarzyństwo. To niszczenie pamięci nie tylko o ostatnich dwóch tysiącach lat historii, ale przede wszystkim o ludziach, którym te nazwiska kiedyś nadano, o ich życiu, po którym często są jedynym śladem, i o drodze, jaką przeszli. Lemberger, co do którego od razu wiadomo, że pochodzi ze Lwowa, Sandauer, którego przodkowie, zanim dotarli do Sambora, na jakimś etapie swojej wędrówki zapewne mieszkali w Sandau nad Łabą i według wszelkiego prawdopodobieństwa zostali stamtąd wygnani — zmiana takich nazwisk, poświadczających jednocześnie żydowskość i punkty zakorzenienia na nieżydowskiej ziemi, byłaby odstępstwem nie mniej radykalnym (a dla niereligijnego Sandauera chyba nawet bardziej rażącym) niż porzucenie wiary ojców.

Najsilniej może poruszający fragment „pamiętnika izraelskiego” to relacja ze spotkania ze starym Maxem Brodem („A Max Brod nie urodził się w Brodach?” — zastanawiają się bohaterowie jednego $\mathrm{z}$ opowiadań Stryjkowskiego) ${ }^{23}$, który opowiada o ,czysto żydowskim” poczuciu wykorzenienia bohaterów Kafki:

Bohater Zamku, ów mierniczy K., który — w radosnym przeświadczeniu, że nareszcie znajdzie miejsce na ziemi — przybywa do wsi, gdzie okazuje się niepożądanym intruzem, czymże jest, jeśli nie symbolem wciąż wpraszającego się i wciąż odtrącanego Żyda? (W 121).

Rodem ze zniemczonej rodziny żydowskiej, osiadłej w Pradze, Kafka czuł się wykorzeniony potrójnie. Jako Niemiec był obcy Czechom, jako Żyd - Niemcom, jako asymilator wreszcie — samym Żydom (W 122).

Sandauer komentuje:

\footnotetext{
${ }^{22}$ W O sytuacji... Sandauer wytyka zmiany nazwisk wielu pisarzom polsko-żydowskim.

${ }^{23}$ J. Stryjkowski, ,Na wierzbach ... nasze skrzypce”, Warszawa 1974, s. 125.
} 
Wywód Broda - w równej mierze co do Kafki — odnosi się do niego samego. Obciążony, jak jego wielki przyjaciel, potrójną przynależnością: żydowską, niemiecką, czeską, wyjechał do Palestyny, aby się nareszcie ujednoznacznić (W 123).

Taka tęsknota za prostą, monolityczną tożsamością jest w wypadku Żydów z diaspory nie tylko nieziszczalna (Brod pozostanie w Izraelu tym, „czym był przez całe życie w Europie: wygnańcem", W 123), ale i — ze wskazanych wyżej powodów — szkodliwa. Sam Sandauer wybiera tożsamość złożoną, można by powiedzieć — kompozytową:

Jeżeli być asymilatorem, to znaczy — zrzekać się jakiejś cząstki w sobie, udawać człowieka z jednej bryły, to nie jestem asymilatorem. Upieram się przy swojej komplikacji i nie mam zamiaru — w imię urojonej jednolitości — wyrzekać się żadnego ze swych składników (W 55).

Jedyna zatem dopuszczalna autodefinicja autora Liryki i logiki musi być dwoista: Żyd-Polak, ,życie żydowskie” (z pisarzy ocalałych z Zagłady miał je w tak dużym stopniu chyba tylko Adolf Rudnicki) — „kultura polska” (B 6). W charakterystycznej dla siebie obiektywizującej formie ${ }^{24}$ pisał o sobie:

Dwoistości tej Sandauer nigdy nie przezwyciężył, problemu samookreślenia nie załatwił. W ogóle - sprzeczności swoich nie rozstrzyga; poddaje je tylko analizie. Jest zawieszony zawsze w wahliwej równowadze ${ }^{25}$.

Ów stan zawieszenia pomiędzy czy ponad tożsamościami składowymi, ponad „dzielnicami” własnego rodowodu, został przez pisarza sfabularyzowany w zakończeniu Zapisków..., zatytułowanym Odejście narodu (z alternatywnym tytułem Sen na strychu). Utrzymana w onirycznej konwencji kafkowska parabola rozwija motyw ,jazdy na stołku" - ślizgania się w powietrzu ponad samborskim Rynkiem, które można odczytać jako figurę psychicznego stanu zawieszenia.

$\mathrm{Z}$ tej pozycji bohater obserwuje ustawiony w czworobok thum ludzi — jakby żywe odwzorowanie kształtu Rynku, na który wyszli uciekinierzy z getta — stojący na skraju samborskiego wzgórza staromiejskiego, twarzami w stronę Targowicy. Ludzie ci trzymają nad głowami rozmaite sprzęty codziennego użytku: „ten sposób ochrony przed deszczem nadawał całości wygląd improwizowanego namiotu [...]” (P 175) — albo wielkiego tałesu, można by dopowiedzieć. Ów wspólny namiot jest jakby odpowiedzią (czyją? nieświadomości Sandauera?) na roztaczaną kiedyś przez wujów syjonistów wizję przyszłości w Erec Israel, gdzie „każdy spocznie pod swoim namiotem” (P 102). Unoszący się dotychczas ponad wzgórzem obserwator traci impet: „zafascynowany widokiem tłumu, zapomniałem o napowietrznej mojej sytuacji i najspokojniej w świecie osiadłem na ziemi w pozycji czekającego na klientów pucybuta" (P 176) - lub żałobnika osieroconego przez najbliższych ${ }^{26}$, chciałoby się znowu dopowiedzieć. Wtedy z milczącego thumu występuje starzec o rysach pradziadka autora - tego, który pozostał na Blichu (jego śmierci poświęcony jest w Zapiskach... osobny rozdział):

\footnotetext{
${ }^{24}$ Więcej na ten temat: M. Wołk, On-ja Artura Sandauera.

25 A. Sandauer, O sytuacji, s. 95.

${ }^{26}$ Por.: A. Unterman, Encyklopedia tradycji, s. 304: „Żałobnik, awel, jeśli jest dzieckiem, współmałżonkiem, rodzicem lub rodzeństwem zmarłego, przez siedem dni po pogrzebie przestrzega ciężkiej żałoby, sziwa. W tym czasie siedzi w domu na niskim taborecie w pożyczonym ubraniu, nie zakłada skórzanego obuwia, nie strzyże się ani nie myje starannie i przyjmuje wizyty członków wspólnoty składających kondolencje".
} 
podszedłszy do mnie udzielił mi lekkim pchnięciem potrzebnego rozpędu. Po chwili znalazłem się z powrotem w powietrzu; ślizgając się już po jego spadzistościach, obejrzałem się jeszcze raz poza siebie i zobaczyłem, jak starzec - był on, dopiero teraz to zauważyłem, ślepy - zaczął zstępować ku dolinie [...]; za nim, nie zmieniając szyku ani pozycji, ruszył tłum, podobny do ruchomego namiotu (P 176).

Ten obraz odwróconej alii ${ }^{27}$ (a zarazem odwróconej asymilacji, bo to przecież zejście z „europejskiego” Rynku) wydaje się równie istotny jak motyw rozpędu (do życia? do tworzenia?) uzyskanego dzięki tym, którzy odeszli. Całość składa się na wzruszające i być może zaskakujące świadectwo długu Sandauera właśnie u tej części narodu: gettowej (w obu znaczeniach, bo i samoizolującej się, i izolowanej), zanurzonej w niepowabnej tradycji, w końcu okrutnie zgładzonej. Ruchomy namiot, pod którym nikt się już nie schroni, przemieszcza się nie ku kibucom Palestyny ani nie w stronę Rynku, lecz ku Targowicy i Blichowi — odległym teraz jak asyryjskie czy babilońskie miasta, choć na mapie przecież tak bliskim.

\section{LITERATURA}

J. Błoński, Autoportret żydowski w literaturze polskiej, [w:] tegoż, Biedni Polacy patrza na getto, Kraków 1994, s. 58-117;

S. Gawliński, Sambor Sandauera, Teksty Drugie 2004 nr 6, s. 225-231; przedruk w: tegoż, Metafory losu. O wspótczesnej literaturze polskiej, Kraków 2005;

H. Gosk, Sambor i okolica. Dwie opowieści geo(poli/poe)tyczne o tym, że w Galicji żyło sie razem, ale osobno (przypadek A. Kuśniewicza i A. Sandauera), Teksty Drugie $2014 \mathrm{nr} 6$, s. 264-282;

I. Karkuszewska, „Problem tożsamości w prozie literackiej, paraliterackiej i dokumentarnej Artura Sandauera”, praca magisterska, Uniwersytet Mikołaja Kopernika w Toruniu, 2005;

S. Kisielewski, Dzienniki, wyd. 2, Warszawa 1997;

A. S. Kowalczyk, Sandauer i „Kultura”, [w:] Artur Sandauer. Pisarz, krytyk, historyk literatury, red. K. Hryniewicz, A. S. Kowalczyk, Warszawa 2014, s. 97-107;

M. G. Levine, Artur Sandauer, [w:] Holocaust Literature, red. S. L. Kremer, London-New York 2003, t. 2, s. $1086-1088$;

Z. Macużanka, Sandauer Artur, PSB, t. 34, Wrocław-Warszawa-Kraków 1992-1993;

J. Madejski, Mit Galicji w twórczości Artura Sandauera, Szczecińskie Prace Polonistyczne 1991 nr 4;

—, Problemy polskiego Żyda na przyktadzie twórczości literackiej i krytycznej Artura Sandauera, [w:] Literackie portrety Żydów, red. E. Łoch, Lublin 1996, s. 89-101;

C. Malaparte, Journal d'un étranger à Paris, Paris 2014;

I. Mityk „Śmierć liberała” - elementy groteskowe w opowiadaniach Sandauera, Kieleckie Studia Filologiczne 1996 t. 6, s. 99-115; przedruk w: tejże, Inne spojrzenie. Groteska wprozie polskiej o wojnie i okupacji, Kielce 1997;

Nowa encyklopedia powszechna PWN, Warszawa 1997;

W. Podoliński, Sambor i okolica. Przeglad krajoznawczy, Sambor 1937;

M. Pollack, Po Galicji. O chasydach, Hucułach, Polakach i Rusinach. Imaginacyjna podróż po Galicji Wschodniej i Bukowinie, czyli Wyprawa w świat, którego nie ma, tłum. A. Kopacki, Olsztyn 2000;

E. Prokop-Janiec, Żyd - Polak - artysta: o budowaniu tożsamości po Zagładzie, Teksty Drugie $2001 \mathrm{nr} 1$, s. 120-134;

A. Sandauer, Bytem..., Warszawa 1991;

27 „Jeszcze dziś imigrację do Izraela określa się tym technicznym terminem «Wznoszenia» («alija»), nadając temu pojęciu sens symboliczny” (W 40). 
-, Death of a Liberal, thum. M. Adamczyk-Garbowska, [w:] Contemporary Jewish Writing in Poland, red. A. Polonsky, M. Adamczyk-Garbowska, Lincoln 2001, s. 135-142;

—, Der Tod eines Liberalen: Erzählungen, tłum. i posłowie U. Usakowska-Wolff, M. Wolff, Bielefeld 2001;

—, La Mort du liberal, Paris 1958;

-, O sytuacji pisarza polskiego pochodzenia żydowskiego $w$ XX wieku. (Rzecz, która nie ja powinienem byt napisać...), Warszawa 1982;

—, Pisma zebrane, Warszawa 1985;

-, Prawo do prawdy, Polityka 1987, nr 8;

—, W 2000 lat później. Pamiętnik izraelski, Warszawa 1956;

—, Zapiski z martwego miasta, [w:] Proza, wyd. 2, Kraków 1974, s. 95-176;

J.-P. Sartre, Rozważania o kwestii żydowskiej, tłum. J. Lisowski, Warszawa 1957;

J. Stryjkowski, „Na wierzbach ... nasze skrzypce”, Warszawa 1974;

„Śnit mi się Artur Sandauer”. Rozmowy i wspomnienia, zebrał i oprac. J. Baran, Kraków 1992;

D. Tubielewicz Mattsson, Artur Sandauer - filozofia mitu, Slovo 1990 t. 39, s. 65-91, online: http://www2.moderna.uu.se/slovo/Archives/1990-39/3.pdf;

A. Unterman, Encyklopedia tradycji i legend żydowskich, przeł. O. Zienkiewicz, wyd. 2 popr., Warszawa 2000;

J. Wierzejska, Watki galicyjskie w twórczości Artura Sandauera (,,Śmierć liberała”, „Zapiski z martwego miasta”, „Bytem...”), [w:] Artur Sandauer. Pisarz, krytyk, historyk literatury, red. K. Hryniewicz, A. S. Kowalczyk, Warszawa 2014, s. 49-64;

M. Wołk, On-ja Artura Sandauera, Litteraria Copernicana 2010 nr 1, s. 100-111;

-, Pułapki świadomości. O labiryntowym cyklu opowiadań Sandauera, [w:] Cykl literacki $w$ Polsce, red. K. Jakowska, B. Olech, K. Sokołowska, Białystok 2001, s. 377-391;

-, Schodki, kanaty, strych. Przestrzeń i ruch w „Zapiskach z martwego miasta”, [w:] tegoż, Gtosy labiryntu. Od „,Śmierci w Wenecji” do „Monizy Clavier”, Torun 2009, s. 74-99;

-, The Holocaust and the Grotesque: the Case of Artur Sandauer's Fiction, Jednak Książki / Books Now $2016 \mathrm{nr}$ 6: The Holocaust and the Contemporary World, s. 187-196, online: http://cwf.ug.edu.pl/ojs/index.php/JednakKsiazki/article/view/409/304;

G. Wołowiec, Nowocześni w PRL. Przyboś i Sandauer, Wrocław 1999;

J. Wróbel, Tematy żydowskie w prozie polskiej 1939-1987, Kraków 1991;

Współcześni polscy pisarze i badacze literatury. Słownik biobibliograficzny, oprac. zespół pod red. J. Czachowskiej i A. Szałagan, t. 7, Warszawa 2001, t. 10, Warszawa 2007.

\section{ARTUR SANDAUER'S TOPOGRAPHY OF IDENTITY}

The article discusses the role of spatial elements in constructing identity in autobiographic texts of the Polish critic and writer Artur Sandauer (1913-1989). Sandauer appears as a writer of space par excellence. It is particularly visible in the interpretations of his own origin. He often makes such self-interpretations, each time giving his lineage a generalised dimension and presenting it not only as a family or ethnic genealogy but also as a cultural origin. He almost always addresses his origins in geographical or topographical categories. Sandauer emphasises that his birthplace, Sambor, was a spatial, historical, cultural and linguistic borderland, showing its distance from cultural and political centres. At the same time he recalls other writers of Jewish origin: Franz Kafka, Bruno Schulz, Max Brod, and implies that ideas and works of fundamental importance to contemporary European culture were born in such peripheral spaces. Sandauer uses spatial terms to speak also about the history of his family and the assimilation of the Jews, shown as a gradual relocation from the Jewish to the Polish quarter. A separate place in Sandauer's mind is occupied by Israel as a space of Jewish salvation on the one hand, and of covering up the traces of the Central European Jewish identity on the other (the hebraisation of surnames and the gradual disappearance of Yiddish). The writer places himself in between these spaces as a "man of the borderland."

KEYWORDS: Artur Sandauer; Polish literature; Jewish literature; identity; space; geopoetics. 